\title{
The Relationships between Students' Perceived Learning Styles and the Community of Inquiry Presences in a Graduate Online Course
}

\author{
http://dx.doi.org/10.3991/ijet.v11i04.5312 \\ Hasnae Mouzouri \\ Faculty of Letters and Human Sciences, Oujda, Morocco
}

\begin{abstract}
In this paper, the author examines whether there is any correlation between students' perceived learning styles with regard to the four domains of Felder and Silverman (2002) and each of the three presences of the Garrison et al.'s Community of Inquiry (CoI) framework (2000): teaching presence, social presence and cognitive presence. First, the CoI survey was administered to a sample of Master students $(\mathrm{N}=\mathbf{2 4})$ at the University Mohamed First in Morocco. Then transcript analysis of online discussion postings was investigated to explore the links of the three presences of the CoI framework with students' selfperceptions of personal learning style preferences. Analysis of the data collected from these instruments revealed significant relationships between students' perceived learning styles with regard to some domains of Felder and Silverman's model and only two presences of the CoI framework: social and cognitive presences. The findings have important implications for how to design online courses in a way that fits students' needs and thus foster effective learning.
\end{abstract}

Index Terms-Learning styles, Cognitive Presence, Teaching Presence, Social Presence, Community of Inquiry, CoI survey, Perceived learning styles, effective learning.

\section{INTRODUCTION}

In the past few years, a vast movement towards the development of online courses in Moroccan universities has been initiated. This movement has opened the door for the implementation of several e-learning projects at a national level. This reflects universities' efforts to introduce ICT (Information and Communication Technologies) in their programs for improving the quality of education. To achieve this objective, it is obvious that the proposed elearning courses have to be designed in a way that fits the learning needs of all students. Therefore, instructors and course designers have tried and are still trying to use theoretical and practical frameworks to ensure the effectiveness of their online programs. Among these frameworks, the Community of Inquiry (CoI) framework, developed by Garrison et al (2000) [1, 2], has been adopted for this study to design, develop and deliver a graduate university online course in our educational context. For many authors, "the Community of Inquiry (CoI) model is a theoretical framework that explains the online learning experience in terms of interactions between three overlapping presences: Teaching, Social and Cognitive" [3]. Our main aim in this paper is to check the relevance of this framework to the students' needs and explore if the students' perceived learning styles with regard to the four domains of Felder and Silverman are associated with the Community of Inquiry presences.

A large number of previous research studies aiming at exploring aspects of the CoI framework have found that this dynamic model should be used "to guide investigations into the research and practice of web-based online teaching and learning" [4]. The research studies' overriding concern was to understand how this model could ensure effective learning in online environments. Although some researchers have investigated and explored a cluster of concepts such as perceived learning (retention) and student satisfaction using correlational studies to provide answers about the CoI framework and its main components, we are convinced that we have to investigate other concepts that are more relevant and central to the $\mathrm{CoI}$ framework. Among these concepts, the perceived learning styles and its correlations with the three presences of the CoI model are investigated in the present study. We note that as today there are 'little if any' research that has studied the correlations between the students' perceived learning styles with regard to the four domains of Felder and Silverman's model and each presence of the Community of Inquiry framework.

\section{THEORETICAL BACKGROUND}

\section{A. The Felder and Silverman's learning styles model}

There are several models in literature about learning styles such as Myers-Briggs (1940), Dunn \& Dunn (1978), Kolb (1984) and Felder \& Silverman (1988). Each of these models relies on specific domains and dimensions to categorize students' modes of learning. This research is based on Felder and Silverman's learning styles model because of its popularity (well-known) and its applicability to e-learning [5].

According to the Felder-Silverman learning styles model $[6,7]$, people learn in many ways. Some of them tend to actively retain information (by discussing or applying it or explaining it to others); others get more from reflecting individually through introspection. Some like learning facts and procedures; others prefer to discover possibilities and relationships. Some learn best when they see (pictures, diagrams, flow charts, time lines, films, and demonstrations); others learn more when information is presented verbally (written and spoken explanations). Some gain understanding in linear steps; others function more globally by grasping information in large jumps '[8].

Based on these individual differences in learning, Felder and Silverman suggest that their model has four do- 
mains related to how information is received (Input), how it is perceived (Perception), how it is processed (Processing) and how it is understood (Understanding). Each domain covers what an individual prefers in respect to these learning aspects.

Thus, these authors $[6,7]$ have formulated their learning styles model with the dimensions shown in Table I.

Felder and Silverman point out that everyone uses all these learning styles dimensions constantly, but most people tend to favor one over the others. To function effectively in any learning environment, all students' personal learning styles should be taken into account in the design of instruction [9]. This means that teachers and designers have to support all learning style preferences by providing information in various formats and using various instructional methods to help students reach their potential for achievement. Evidently, this will help them developing their skills in both their preferred and less preferred modes of learning. So, their learning needs will be met effectively.

There are many ways of identifying students' learning styles in literature that rely on the use of specific questionnaires and scales, but most of them have received considerable criticism since, in the majority of cases, there is a mismatch between questionnaire answers and students' real behavior patterns and perception of their learning styles [5]. Moreover, these learning styles instruments are accused of organizing numerical results:

"into a few discrete, quantitative, often dichotomous categories rather than recognizing that individuals develop and practice a qualitative mixture of learning styles that evolve as they learn and grow and that vary by discipline..." [10].

For the present study, we collected information about the students' learning styles by allowing them to express their self-perceptions about their most preferred modes of learning and describe their own behavior patterns qualitatively at the end of the course through their responses to a few open-ended questions which were included in the CoI survey.

\section{B. The Garrison et al. 's Community of Inquiry frame- work}

Having developed a Community of Inquiry, or $\mathrm{CoI}$ for short, as a framework for explaining a deep and meaningful learning experiences [1], Garrison et al. (2000) report three basic interrelated elements in their framework, namely: social presence, teaching presence and cognitive presence.

"Social presence refers to the degree to which learners feel socially and emotionally connected with others in an online environment; teaching presence is defined as the design, facilitation, and direction of cognitive and social processes for the realization of personally meaningful and educationally worthwhile learning outcomes; and cognitive presence describes the extent to which learners are able to construct and confirm meaning through sustained reflection and discourse" [11].

The categories and indicators of each of the three presences that form the CoI framework are shown in the table II.

According to Garrison et al (2000) [12, 13], learning effectiveness and practices are associated with these three types of presence. They state that:
TABLE I.

DIMENSIONS OF FELDER AND SILVERMAN LEARNING STYLES MODEL [6]

\begin{tabular}{|l|l|}
\hline \multicolumn{2}{|c|}{ Dimensions of Felder and Silverman learning styles model } \\
\hline $\begin{array}{l}\text { Sensing (facts, processes) / Intuitive (concepts, } \\
\text { relationships) }\end{array}$ & Perception \\
\hline $\begin{array}{l}\text { Visual (seeing, picturing) / Verbal (hearing, read- } \\
\text { ing, saying) }\end{array}$ & Input \\
\hline Active(doing) / Reflective (thinking) & Processing \\
\hline Sequential (step-wise) / Global (leaps, random) & Understanding \\
\hline
\end{tabular}

TABLE II.

CATEGORIES AND INDICATORS OF THE COI PRESENCES [2]

\begin{tabular}{|c|c|c|}
\hline Presences & Categories & Indicators \\
\hline $\begin{array}{l}\text { Cognitive } \\
\text { presence }\end{array}$ & $\begin{array}{l}\text { Triggering events } \\
\text { Exploration } \\
\text { Integration } \\
\text { Resolution }\end{array}$ & $\begin{array}{l}\text { Sense of puzzlement } \\
\text { Information exchange } \\
\text { Connecting ideas } \\
\text { Apply new ideas }\end{array}$ \\
\hline $\begin{array}{l}\text { Teaching pres- } \\
\text { ence }\end{array}$ & $\begin{array}{l}\text { Design and organization } \\
\text { Facilitating discourse } \\
\text { Direct instruction }\end{array}$ & $\begin{array}{l}\text { Setting curriculum and } \\
\text { methods } \\
\text { Sharing personal meaning } \\
\text { Focusing discussion }\end{array}$ \\
\hline Social presence & $\begin{array}{l}\text { Affective } \\
\text { Open communication } \\
\text { Group cohesion }\end{array}$ & $\begin{array}{l}\text { Expressing emotions } \\
\text { Risk-free expression } \\
\text { Encouraging collaboration }\end{array}$ \\
\hline
\end{tabular}

"The challenge of educators is to link the properties of [...] online learning with the ability to create communities of learning and inquiry that integrates the cognitive, social and teaching presence to meet individual and societal needs" [14].

But how should these three types of presence be integrated in online learning environments in a way that helps each student (whatever his/her learning style) reach his/her potential of achievement?

It is noted by some researchers that "Teaching around the cycle" was required to meet the individual and societal learning needs of the full spectrum of learning styles [8]. This involves the use of various instructional methods at once such as: the presentation of the course objectives and scenario; providing different presentations of the course material; providing basic theoretical and conceptual information and complementary resources; individual and collaborative activities; team projects, guided practices and real-world application; providing regular support and mentoring; etc.

Evidently, the combination of these methods brings about the achievement of a "Community of Inquiry" since all students, whatever their learning styles, will be involved in the course somehow. Thus, they will have an education that addresses both their strengths and weaknesses [8].

Despite the fact that differences in students' behaviors, as far as learning processes and outcomes are concerned, have been the motivation of several research studies which have investigated the $\mathrm{CoI}$ framework for a long time, little if nothing is known about what effect does each of the three presences of the Community of Inquiry framework have on students' perceived learning styles? What type (s) of presence is (are) associated with the students' perceived learning styles? And finally which differences in the CoI presences can be found in relation to the students' perceived learning styles with regard to learning styles domains? 
In the study reported here, The CoI framework was used in relation to students' perceived learning styles to give some answers to these questions, to understand the basis of students' performance and to identify appropriate teaching approaches that support deep and meaningful learning (the central claim of the CoI framework) [15].

\section{Methodology}

The focus of this study was one of the graduate online courses offered by the University Mohamed First in Morocco (Faculty of Letters and Human Sciences Oujda) in the fall term of 2014. The course was delivered completely online using the platform Moodle. It was a three-week course about Interactive Animations (IA).

Students $(\mathrm{N}=24)$ enrolled in this master's level course were $75 \%$ male and $25 \%$ female. They were informed by the instructor about the course objectives and scenario (assignments, responsibilities...) in the first synchronous meeting through GoToWebinar.

Since the course was designed and developed in light of the CoI framework, the instructor provided the 'teaching presence' by moderating and facilitating online discussions using asynchronous and synchronous tools of communication (Forum, Chatroom and GoToWebinar). This did not prevent him from distributing the teaching presence by encouraging students to moderate and facilitate the weekly online discussion forums in turns. This interactive teaching and learning way provided additional assistance to each student who needed it. Thus, the authoritative influence of the instructor was attenuated [2].

The course material was presented in various formats (tutorials, video lectures, written documents...) to address the preferences of multiple learning styles. The requirements of the course were as following:

- Participating actively in the course (sharing ideas, asking questions about the course content, providing support and feedback to each other's work...) ;

- Submitting a quiz and an assignment each week.

Thirty percent of students' final grades were based on their participation in the course, twenty percent came from quizzes and the remaining came from assignments (a production learning activity, a problem-solving situation and the team project) submitted to the instructor for grading.

This study applied a mixed approach to explore the relationships between students perceived learning styles with regard to the four domains of Felder and Silverman's model and each presence of the CoI framework. The reason for this is that it was crucial for us to collect some data that are qualitative and some data that are quantitative to strengthen the results (for more credibility) and gain a better understanding of the research problem. As Creswell \& Clark [16] stated:

"Qualitative research and quantitative research provide different pictures, or perspectives, and each has its limitations. When researchers study a few individuals qualitatively, the ability to generalize the results to many is lost. When researchers quantitatively examine many individuals, the understanding of any one individual is diminished. Hence, the limitations of one method can be offset by the strengths of the other method, and the combination of quantitative and qualitative data provide a more complete understanding of the research problem than either approach by itself."

\section{A. The instruments}

\section{1) CoI survey}

Students were asked to complete the CoI survey administered to them via LimeSurvey at the end of the course. This survey, created by Garrison and colleagues, included 34 items corresponding to a 5 point Likert scale (13 items for teaching presence perception, 9 items for social presence perception and 12 items for cognitive presence perception). It was translated into French by the author and four English language instructors and piloted before administrating it to the actual students.

To explore the relationships between the perceived learning styles and the three types of the CoI presences, we have included four items for perceived learning styles in the survey. One of these items was a multiple choice question about how students perceive their personal learning style preferences, and the remaining three items were open-ended questions about how students describe themselves with regard to the four domains of Felder and Silverman's model and which factor they believe that influenced their learning most.

Quantitative data were gathered from students' responses to the 5 point Likert scale questions about the CoI presences and the multiple choice question about student's perceived learning styles (Q35: Which word would best describe your learning style? Responses: a/Active, b/Reflective, c/Visual, d/Verbal, e/Sensing, f/Intuitive, g/Sequential, h/Global, i/No preference, j/Equal preference). As far as the remaining open-ended questions are concerned, the author analyzed them qualitatively with the help of the content analysis method proposed by L'Écuyer (1990) and Huberman \& Miles (1991, 1994).

The following open-ended questions were used in the survey:

Q36. Please describe (in a few words) how do you think that you learn best?

Q37. Can you give me an example of a learning situation which was successful for you and tell me what did you do to study well?

Q38. Which factor do you believe influenced your learning most?

Twenty-one (out of 24) students responded to the survey.

\section{2) Transcript analysis}

Transcript analysis of online discussion forums was used to study the relationships between the CoI presences and the perceived learning styles with regard to the four domains of Felder and Silverman's model. Coding was done in phases based on category indicators of each presence of the CoI framework (see table II). The coding procedure was to code the instructor and students' postings for each of three presences at the message-level as a unit of analysis. Garrison [17] noted that: "a message may contain any number or combination of sentences, fragments, and paragraphs". This means that any number or combination of the three presences might be found in one message. So considering a message as a unit of analysis in this study makes it more credible. 
The author coded the instructor and students' postings by applying the content analysis method with the following three phases:

Phase 1: Reading all texts repeatedly to identify meaningful units (key words, concepts, phrases, paragraphs...) and classify them under the categories of each presence of the CoI framework. It should be noted here that the author explored postings patterns of social presence by coding for affective expression, open communication and group cohesion. Cognitive presence was coded for triggering event, exploration, integration and resolution. Finally, teaching presence was coded for design and organization, facilitating discourse and direct instruction. Table III illustrates the coding scheme for each presence.

Phase 2: Quantification and statistical treatment of the gathered data using descriptive methods and correlation analysis.

Phase 3: Interpretation of results.

Three research questions were posed:

1. How students perceive the CoI presences in this study?

2. What learning styles (with regard to the four domains of Felder and Silverman's model) were found in the study group? And do the CoI presences make an impact on students' learning styles?

3. Is there a statistically significant relationship between each presence of the $\mathrm{CoI}$ framework and students' perceived learning styles with regard to the four domains of Felder and Silverman's model?

\section{B. Results}

\section{1) The CoI survey analysis}

In order to answer our research questions, descriptive statistics and correlational analysis were performed.

\section{Research question 1:}

The mean score of responses for teaching presence was 4.68, for social presence 4.21 and for cognitive presence 4.42. This means that the frequency of students' agreement regarding each item from the CoI survey was high. Therefore, students perceived the three types of presence of the CoI framework positively (the means show high level of satisfaction).

\section{Research question 2:}

The analysis of students' responses to questions about which learning style (LS) they believed described them best showed that the majority of them classified themselves as being sensing $(n=13)$, visual $(n=15)$, active $(n=16)$ and sequential $(n=16)$ (see Figure1).

Students' responses to open-ended questions in the survey indicated that students believe that they study well when teaching, social and cognitive presences are provided in sufficient levels. Most of students also emphasized the positive influence that the CoI presences had on their way of receiving, perceiving, processing and understanding information. Given this, some students indicated that teaching presence, social presence and cognitive presence are key for their engagement in the course discourse and activities.
TABLE III.

CODING SCHEME FOR EACH PRESENCE OF THE COI FRAMEWORK

\begin{tabular}{|c|c|c|}
\hline $\begin{array}{l}\text { The CoI } \\
\text { presences }\end{array}$ & Indicators & Examples \\
\hline $\begin{array}{l}\text { Social pres- } \\
\text { ence }\end{array}$ & $\begin{array}{l}\text { Affective expression } \\
\text { Open communication } \\
\text { Group cohesion }\end{array}$ & $\begin{array}{l}\text { "Student Introduction, express- } \\
\text { ing emotions" } \\
\text { "Complimenting and responding } \\
\text { to the questions of others" } \\
\text { "Addressing or referring to } \\
\text { students by name, encouraging } \\
\text { collaboration" }\end{array}$ \\
\hline $\begin{array}{l}\text { Cognitive } \\
\text { presence }\end{array}$ & $\begin{array}{l}\text { Triggering event } \\
\text { Exploration } \\
\text { Integration resolution }\end{array}$ & $\begin{array}{l}\text { "Asking questions, identifying } \\
\text { problems" } \\
\text { "Information exchange" } \\
\text { "Developing new ideas" } \\
\text { "Applying new ideas" }\end{array}$ \\
\hline $\begin{array}{l}\text { Teaching } \\
\text { presence }\end{array}$ & $\begin{array}{l}\text { Design and organiza- } \\
\text { tion }\end{array}$ & $\begin{array}{l}\text { "providing guidelines on how to } \\
\text { perform individual and group } \\
\text { activities" } \\
\text { "Encouraging, acknowledging or } \\
\text { reinforcing student contribu- } \\
\text { tions" } \\
\text { "Focusing the discussion on } \\
\text { specific issues, summarizing the } \\
\text { main ideas" }\end{array}$ \\
\hline
\end{tabular}

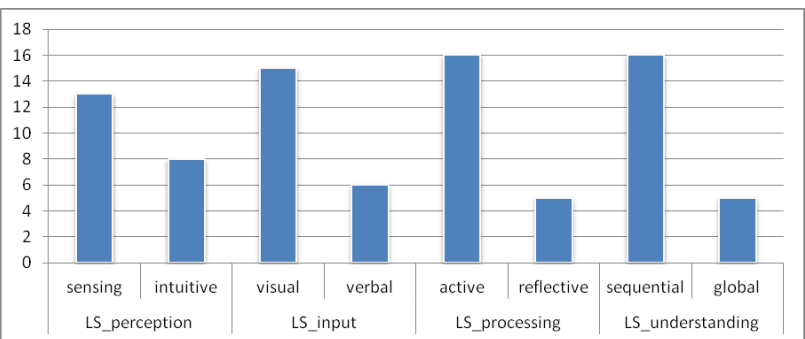

Figure 1. Students' perceived learning styles (LS) with regard to each domain of Felder and Silverman's model (2000)

\section{Research question 3:}

The relationships between students' perceived learning styles with regard to the four domains of Felder and Silverman's model and the CoI presences were explored using the Spearman Rank Correlation Coefficient (see Tables: IV and V). For the analysis, the variables were defined as each presence of community of inquiry framework (teaching presence, social presence, and cognitive presence) and each domain of Felder and Silverman learning styles (LS) model (Input, Perception, Processing, Understanding).

The correlational analysis, as shown in table IV, revealed that there was a positively significant relationship between social presence and the learning style domain related to perception of information $(\mathrm{r}=.547, \mathrm{p}=.010)$, and a negatively significant relationship between social presence and the learning style domain concerned with processing of information $(\mathrm{r}=-.503, \mathrm{p}=.020)$. This indicates that the positive perception of social presence influences the way students perceive the information given to them in online learning environments positively. This also indicates that the perception of higher levels of social presence is associated with lower processing of information.

The results in Table $\mathrm{V}$ shows a significant relationship between cognitive presence and the learning style domain related to perception of information $(r=.510, p=.018)$, between cognitive presence and the learning style domain 
concerned with reception of information $(r=.540, p=.012)$, and between cognitive presence and the learning style domain which focuses on how information is processed $(\mathrm{r}=-.497, \mathrm{p}=.022)$. This indicates that the positive perception of cognitive presence influences the way students perceive, receive and process the information presented to them in online learning environments. In other words, students who perceived higher levels of cognitive presence perceived and received information positively. However, their processing of information is lower (the coefficient of correlation is negative).

The correlational analysis indicates a non-significant relationship between teaching presence and students' perceived learning styles with regard to the four domains of Felder and Silverman's model (2000). This shows that even if students perceived the teaching presence positively, this has no influence on their self-perceptions of personal learning style preferences. It seems that the low authority of the instructor and the distribution of the teaching presence throughout the course were the main reasons for these findings.

Overall, we can conclude that social presence influences information perception positively and information processing negatively, whereas the cognitive presence affects information reception, perception positively and information processing negatively.

2) The transcript analysis

Students' online discussion forums were recorded and examined using the content analysis method and the categories of the CoI presences as a coding scheme (see Table III). The main purpose was to explore whether the CoI presences are associated with students' perceived learning styles with regard to the four domains of Felder and Silverman's model.

The instructor created the general area for discussion each week. Students were informed they were expected to actively participate in discussion forums by sharing their ideas and opinions, discussing the course requirements and asking/replying to questions regarding the course content and process. Thus, the discussion ranged over various topics such as ergonomic criteria for the evaluation of interactive animations, and the pedagogical use of the software E-Anim.

Content analysis was conducted on a total of 92 discussions. There were a total of 695 posts in the course. As we have previously reported the unit of analysis was the message. The author coded each message within the transcript based on the Community of Inquiry (CoI) coding scheme (see Table III).

\section{Learning styles and communication patterns:}

Students who perceived themselves as being active learners $(n=13)$ made significant postings compared to the reflective students $(\mathrm{n}=8)$. Their postings were particularly related to cognitive and social presences (see table VI). This is consistent with the Felder and Silverman model which had expected from active learners their engagement and tendency to interact with others and to perform work in group. Regarding communication, Felder and Silverman posit that active learners differ from reflective learners in their preferences for interacting with others. They found that active learners expressed a preference for social/collaborative learning, whereas reflective learners expressed a preference for individually/solitary learning.
TABLE IV

RELATIONSHIPS BETWEEN SOCIAL PRESENCE AND INFORMATION PERCEPTION AND PROCESSING

\begin{tabular}{|c|c|c|}
\hline & LS_perception & LS_processing \\
\hline Spearman's rho Social presence & & \\
Correlation Coefficient &, $547^{*}$ &,$- 503^{*}$ \\
Sig. (2-tailed) &, 010 &, 020 \\
$\mathrm{~N}$ & 21 & 21 \\
\hline
\end{tabular}

**. CORRELATION IS SIGNIFICANT AT THE 0.01 LEVEL (2-TAILED).

*. CORRELATION IS SIGNIFICANT AT THE 0.05 LEVEL (2-TAILED).

TABLE V.

RELATIONSHIPS BETWEEN COGNITIVE PRESENCE AND INFORMATION RECEPTION, PERCEPTION AND PROCESSING

\begin{tabular}{|c|c|c|c|}
\hline & LS_perception & LS_Input & LS_processing \\
\hline Spearman's rho & & & \\
Cognitive presence & & & \\
Correlation Coefficient &, $510^{*}$ &, $540^{*}$ &,$- 497^{*}$ \\
Sig. (2-tailed) &, 018 &, 012 &, 022 \\
N & 21 & 21 & 21 \\
\hline
\end{tabular}

**. CORRELATION IS SIGNIFICANT AT THE 0.01 LEVEL (2-TAILED).

*. CORRELATION IS SIGNIFICANT AT THE 0.05 LEVEL (2-TAILED).

TABLE VI.

NUMBERS OF MESSAGES IN EACH PRESENCE FOR ACTIVE/REFLECTIVE LEARNERS

\begin{tabular}{|c|c|c|c|}
\hline $\begin{array}{c}\text { Numbers of } \\
\text { messages } / \text { The } \\
\text { CoI presences }\end{array}$ & $\begin{array}{c}\text { Active learners } \\
(\mathbf{n = 1 3 )}\end{array}$ & $\begin{array}{c}\text { Reflective } \\
\text { learners }(\mathbf{n}=\mathbf{8})\end{array}$ & Total (n=21) \\
\hline Teaching presence & 8 & 3 & 11 \\
\hline Social presence & 154 & 46 & 200 \\
\hline $\begin{array}{c}\text { Cognitive pres- } \\
\text { ence }\end{array}$ & 367 & 79 & 446 \\
\hline Total & $\mathbf{5 2 9}$ & $\mathbf{1 2 8}$ & $\mathbf{6 5 7}$ \\
\hline
\end{tabular}

Table VII shows the total number of messages posted each week and the distributions of the CoI presences in the transcripts of the course.

TABLE VII.

THE NUMBERS OF MESSAGES POSTED EACH WEEK WITH REGARD TO THE COI PRESENCES

\begin{tabular}{|l|c|c|c|c|}
\hline \multicolumn{1}{|c|}{ Presences/weeks } & Week 1 & Week 2 & Week 3 & $\begin{array}{c}\text { Total of } \\
\text { messages }\end{array}$ \\
\hline Teaching presence & & & & \\
\hline Design and organization & 2 & 2 & 1 & 5 \\
\hline Facilitating discourse & 10 & 3 & 1 & 14 \\
\hline Direct instruction & 7 & 3 & 1 & 11 \\
\hline No category & 0 & 0 & 0 & 0 \\
\hline Cognitive presence & & & & \\
\hline Triggering event & 5 & 14 & 15 & 34 \\
\hline Exploration & 38 & 76 & 47 & 161 \\
\hline Integration & 40 & 115 & 72 & 227 \\
\hline Resolution & 4 & 13 & 7 & 24 \\
\hline No category & 0 & 0 & 0 & 0 \\
\hline Social presence & & & & \\
\hline Affective expression & 27 & 30 & 18 & 75 \\
\hline Open Communication & 20 & 37 & 41 & 98 \\
\hline Group cohesion & 5 & 13 & 9 & 27 \\
\hline No category & 0 & 10 & 9 & 19 \\
\hline Total of messages & 158 & 316 & 221 & 695 \\
\hline
\end{tabular}


Table VII also shows that the majority of messages posted each week are related to cognitive and social presences. The second week was the best week in terms of interaction. Indeed both the cognitive and social presences had increased in terms of the message numbers. This finding is due to the fact that the course assignment for this week which was a production learning activity had raised many important issues for discussion. During this week, students have been asked to produce an interactive animation using the software E-Anim, thus most of them faced many technical problems.

The high number of messages confirms that students really perceived positively the three presences of the CoI framework, particularly the social and cognitive presences. This is what indicates their engagement in the course discourse.

The correlational analysis of the numbers of messages for each presence in relation to students' perceived learning styles with regard to the four domains of Felder and Silverman's model (see Table VIII) indicates a significant relationship between the numbers of messages related to cognitive presence and perception of information $(\mathrm{r}=.448$, $\mathrm{p}=.042$ ), between the numbers of messages related to cognitive presence and information processing $(\mathrm{r}=-.622$, $\mathrm{p}=.003$ ). This indicates that when perceiving highly the cognitive presence, both perception and processing of information are affected. Indeed, a higher level of engagement in discourse is associated with higher levels of information perception but with lower levels of information processing.

Table IX shows that there was a significant relationship between the numbers of messages related to social presence and information perception $(\mathrm{r}=.521, \mathrm{p}=.015)$, and between the numbers of messages related to social presence and information reception $(\mathrm{r}=.541, \mathrm{p}=.011)$. This indicates that the positive perception of social presence affected positively both reception and perception of information.

TABLE VIII.

RELATIONSHIPS BETWEEN NUMBERS OF MESSAGES RELATED TO COGNITIVE PRESENCE AND INFORMATION PERCEPTION AND PROCESSING

\begin{tabular}{|c|c|c|}
\hline & LS_perception & LS_processing \\
\hline Spearman's rho & & \\
Nbr. messages related & & \\
to Cognitive presence & & \\
Correlation Coefficient &, $448^{*}$ &,$- 622^{* *}$ \\
Sig. (2-tailed) &, 042 &, 003 \\
N & 21 & 21 \\
\hline
\end{tabular}

**. CORRELATION IS SIGNIFICANT AT THE 0.01 LEVEL (2-TAILED).

*. CORRELATION IS SIGNIFICANT AT THE 0.05 LEVEL (2-TAILED).

TABLE IX.

RELATIONSHIPS BETWEEN NUMBERS OF MESSAGES RELATED TO SOCIAL PRESENCE AND INFORMATION PERCEPTION AND RECEPTION

\begin{tabular}{|c|c|c|}
\hline & LS_perception & LS_Input \\
\hline $\begin{array}{c}\text { Spearman's rho } \\
\text { Nbr. messages related } \\
\text { to Social presence }\end{array}$ & & \\
$\begin{array}{c}\text { Correlation Coefficient } \\
\text { Sig. (2-tailed) }\end{array}$ &, $521^{*}$ &, $541^{*}$ \\
N &, 015 &, 011 \\
& 21 & 21 \\
\hline
\end{tabular}

**. CORRELATION IS SIGNIFICANT AT THE 0.01 LEVEL (2-TAILED).

*. CoRrelation is SIGNIFICANT AT THE 0.05 LEVEL (2-TAILED).
The correlational analysis did not find a significant relationship between numbers of messages related to teaching presence and students perceived learning styles with regard to each domain of the Felder and Silverman's model.

Responses of students related to which factor influenced best their learning indicated that the teaching presence was the most important factor which had influenced them positively. They stated that the synchronous meetings via GoToWebinar and the regular feedback given by the instructor were beneficent and very useful for keeping their motivation and stimulating their engagement. The majority of students $(75 \%)$ pointed out that they felt a change in their actual behaviors with regard to learning style since there were sufficient levels of social, cognitive and teaching presences. This confirms the assumption of some theories of learning styles which assume that learning style preference is not a static condition [10]. These theories suggest that learning is shaped by socio-cultural factors.

\section{DISCUSSION}

The purpose of this study was to explore whether there is any relationship between students' perceived learning styles with regard to the four domains of Fleder and Silverman's model and each presence of the CoI framework. At first it should be noted that students perceived the three CoI presences integrated in the course positively and as reported by them, this influenced somewhat their learning styles. Overall, the CoI presences were considered to be key for students' engagement in the course discourse and activities.

When analyzing the survey results of correlations between the main variables (each presence of the CoI framework and each domain of Felder and Silverman's learning styles model), it was found that significant relationships exist between social presence and students' perceived learning styles related to information perception and processing, and cognitive presence and the three learning styles domains concerned with information reception, perception and processing. These findings reinforce previous studies in terms of the role of students' learning styles and the online interaction in effective learning. Indeed, literature of the CoI framework argues that: in "an environment that is supportive intellectually and socially, and with the guidance of a knowledgeable instructor, students will engage in meaningful discourse and develop personal and lasting understandings of course topics." [18]. Furthermore, it was argued in social learning theories that in order to construct and confirm meaning, learners need to feel connected to another and as if they belonged to a community (social presence). This feeling is crucial because it allows the individual cognitive development (Doise \& Mugny, 1984) which means creating and developing new ways of receiving, perceiving, processing and understanding information.

The finding that students who perceived higher levels of social presence perceived lower levels of information processing indicates that there are some students who may find the social interaction unnecessary and inimical [19]. Thus their involvement in social interaction may be low. Similarly, when perceiving higher levels of cognitive presence information processing is affected negatively. These results suggest that while the positive perception of cognitive presence is expected to lead to more involvement in online discourse, the actual cognitive interaction 
is still be the most challenging to develop in online courses [20].

The findings of the transcript analysis show significant relationships between social interaction and learning style domains related to information reception and perception and cognitive interaction and students' perceived learning styles concerned with information perception and processing. This suggests, as stated by Fahy \& Ally [18], "that even in an environment in which the complete learning cycle might be intended, individual differences in amounts and types of interaction may still be expected". This also indicates that the integration of the presences of the CoI framework in online courses is really linked to the development of cognition of learners who have different levels of motivation, different attitudes about learning and different responses to online learning environments and teaching methods [10].Thus, it is obvious that learning styles domains are associated with social and cognitive presences.

Neither CoI survey analysis nor the transcript analysis showed significant relationships between teaching presence and students' perceived learning styles domains. This is at odds with previous studies where teaching presence was found to be a noteworthy process needed to create paths to epistemic engagement and cognitive presence for online learners [3] and inextricably intertwined with the remaining CoI presences. As we have stated above, this finding could be interpreted by the distribution of teaching among students and the low authority of the instructor throughout the course. But no definitive explanation can be affirmed here. Research is needed to clarify this point.

\section{CONCLUSION AND FUTURE RESEARCH}

There are some limitations in this research study which are related essentially to its settings, the small size of the sample, and the eventual subjectivity of the author when performing transcript analysis of online discussions. Thus the generalization of the results to other educational contexts is questionable.

Results of this study provide evidence that social and cognitive presences of the $\mathrm{CoI}$ framework are linked to students' perceived learning styles with regard to some domains of the Felder and Silverman's model. On the other hand teaching presence was not associated with any domain of learning styles model of Felder and Silverman but it was found important for student learning.

Through this study, we discovered the links between two presences of the CoI framework (social and cognitive presences) and three learning styles domains: information reception, perception and processing.

Based on these results, it appears that by integrating the CoI presences in online learning environments in a way that helps each student (whatever his/her learning styles) reach his/her potential of achievement, students will engage more in the course discussions and activities and this affects (to some extent) their way of receiving, perceiving, and processing the information presented to them at different levels.

These findings suggest opportunities for future researches to be performed to explore the dynamic relationships between specific categories of the CoI presences and the learning style dichotomies (a particular type and/or combination of learning styles). Moreover, the findings open the door for the exploration of the various possibili- ties of integrating the CoI presences in online courses in a way that matches students' personal learning style preferences. This is what will enable us to understand how courses should be designed to help learners to derive the best achievement in online learning environments.

\section{REFERENCES}

[1] Akyol, Z., B. Arbaugh, M. Cleveland-Innes, R. Garrison, P. Ice, J. Richardson and K. Swan. A response to the review of the Community of Inquiry Framework. Journal of Distance Education 23(2): 123-136, 2009. Retrieved from: http://ijede.ca/index.php/ jde/article/view/630/885

[2] Akyol, Z. and D. R. Garrison. The development of a community of inquiry over time in an online course: Understanding the progression and integration of social, cognitive and teaching presence. Journal of Asynchronous Learning Networks 12(3): 3-22, 2008. Retrieved from: http://repositorio.ub.edu.ar:8080/xmlui/ bitstream/handle/123456789/2256/EJ837483.pdf?sequence=1

[3] Boston, W., Díaz, S. R., Gibson, A. M., Ice, P., Richardson, J., \& Swan, K. An exploration of the relationship between indicators of the community of inquiry framework and retention in online programs. 2014. Retrieved from: http://184.168.109.199:8080/ xmlui/bitstream/handle/123456789/2259/EJ862358.pdf?sequence $=1$

[4] Garrison, D. Randy, Martha Cleveland-Innes, and Tak Shing Fung. "Exploring causal relationships among teaching, cognitive and social presence: Student perceptions of the community of inquiry framework." The Internet and Higher Education 13.1: 3136, 2010. Retrieved from: http://www.anitacrawley.net/Articles/ GarrisonClevelandInnesFung2010.pdf, http://dx.doi.org/10.1016/ j.iheduc.2009.10.002

[5] Şimşek, Ö., Atman, N., İnceoğlu, M. M., \& Arikan, Y. D. Diagnosis of Learning Styles Based on Active/Reflective Dimension of Felder and Silverman's Learning Style Model in a Learning Management System. In :Computational Science and Its ApplicationsICCSA 2010. Springer Berlin Heidelberg, 2010. p. 544-555. Retrieved from: https://www.academia.edu/631418/Diagnosis_of Learning_Styles Based_on_Active_Reflective_Dimension_of_Fel der and Silverman s Learning Style Model in a Learning Ma nagement System

[6] Felder, Richard M., and Linda K. Silverman. "Learning and teaching styles in engineering education." Engineering education 78.7 (1988): 674-681.

[7] Felder, Richard M., and Rebecca Brent. "Understanding student differences." Journal of engineering education 94.1 (2005): 57-72. Retrieved from: http://eprints.me.psu.ac.th/ILS/info/Understandi ng_Differences.pdf http://dx.doi.org/10.1002/j.2168-9830.2005. tb00829.x

[8] Felder, Richard M. "Matters of style." ASEE prism 6.4 (1996): 1823. Retrieved from: http://www2.eesc.usp.br/aprende/images/ arquivos/Matters of Style.pdf

[9] Becker, Katrin. "Games and learning styles." (2005). Retrieved from:http://dspace.ucalgary.ca/bitstream/1880/46706/1/Games Le arning 2005.pdf

[10] Willems, Julie. "Does style matter? Considering the impact of learning styles in e-learning." ICT: Providing choices for learners and learning. Proceedings ascilite Singapore 2007. 2007.

[11] Swan, K., Shea, P., Richardson, J., Ice, P., Garrison, D. R., Cleveland-Innes, M., \& Arbaugh, J. B. Validating a measurement tool of presence in online communities of inquiry. E-mentor, 2008, vol. 2, no 24, p. 1-12. Retrieved from: http://www.e-mentor.edu.pl/ artykul/index/numer/24/id/543

[12] Garrison, D. Randy. Online Community of Inquiry Review: Social, Cognitive, and Teaching Presence Issues. Journal of Asynchronous Learning Networks, vol. 11, no 1, p. 61-72, 2007.

[13] Garrison, D. R. Communities of inquiry in online learning: Social, teaching and cognitive presence. Encyclopedia of distance and online learning, p. 352-355, 2009.

[14] Garrison, D. Randy. "Cognitive presence for effective asynchronous online learning: The role of reflective inquiry, self-direction and metacognition." Elements of quality online education: Practice and direction, 2003, vol. 4, p. 47-58. Retrieved from: https://www.researchgate.net/profile/D Garrison/publication/2285 
PAPER

The Relationships between Students’ Perceived Learning Styles And the Community of InQuiRy Presen...

85404 Cognitive presence for effective asynchronous online 1 earning_The_role_of_reflective_inquiry_self-direction_and_meta cognition/links/02bfe50db023b07263000000.pdf

[15] Shea, Peter et BIDJERANO, Temi. Community of inquiry as a theoretical framework to foster "epistemic engagement" and "cognitive presence" in online education. Computers \& Education, vol. 52, no 3, p. 543-553, 2009. http://dx.doi.org/10.1016/j.compedu. 2008.10.007

[16] Clark, Vicki L. Plano et Creswell, John W. Designing and conducting mixed methods research. 2011.

[17] Garrison, D. R., M. Cleveland-Innes, M. Koole \& J. Kappelman. Revisiting methodological issues in the analysis of transcripts: Negotiated coding and reliability. The Internet and Higher Education 9(1): 1-8, 2006. Retrieved from : http://auspace.athabascau.ca :8080/bitstream/2149/611/1/sdarticle.pdf http://dx.doi.org/10.1016/j.iheduc.2005.11.001

[18] Rourke, Liam et Kanuka, Heather. Learning in communities of inquiry: A review of the literature (Winner 2009 Best Research Article Award).International Journal of E-Learning \& Distance Education, vol. 23, no 1, p. 19-48, 2009.

[19] Fahy, Patrick J. et Ally, Mohamed. Student learning style and asynchronous computer-mediated conferencing (CMC) interac- tion. The American Journal of Distance Education, vol. 19, no 1, p. 5-22, 2005. Retireved from : http://auspace.athabascau.ca:8080/ bitstream/2149/685/1/fahy\%20\&\%20ally-kolb-aug\%2004.doc

[20] Garrison, D. R., and J. B. Arbaugh. Researching the community of inquiry framework: Review, issues, and future directions. The Internet and Higher Education 10(3): 157-172, 2007. http://dx.doi.org/10.1016/j.iheduc.2007.04.001

\section{AUTHOR}

Hasnae Mouzouri is a Doctoral student at University Mohammed first, Faculty of Letters and Human Sciences, member of the research team LIMTEC (Langues, Imaginaire et Médiation Technologique), Oujda, Morocco. She received her Master in Didactic and Educational technologies from Mohammed First University. (e-mail: mouzouri.hasnae@gmail.com ).

Submitted 29 November 2015. Published as resubmitted by the author 24 January 2016. 